Article

\title{
Maintenance of Genetic Diversity in Natural Spawning of Captively-Reared Endangered Sockeye Salmon, Oncorhynchus nerka
}

\section{Ruth E. Withler *, David S. O'Brien, Nicolette M. Watson and K. Janine Supernault}

Fisheries and Oceans Canada, Pacific Biological Station, 3190 Hammond Bay Road, Nanaimo, BC V9T 6N7, Canada; E-Mails: David.OBrien@dfo-mpo.gc.ca (D.S.O.);

Nicolette.Watson@dfo-mpo.gc.ca (N.M.W.); Janine.Supernault@dfo-mpo.gc.ca (K.J.S.)

* Author to whom correspondence should be addressed; E-Mail: Ruth.Withler@dfo-mpo.gc.ca; Tel.: +1-250-756-7148; Fax: +1-250-756-7053.

Received: 13 January 2014; in revised form: 3 June 2014 / Accepted: 3 June 2014 /

Published: 19 June 2014

\begin{abstract}
Captive propagation of Pacific salmon is routine, but few captive breeding programs have been conducted to successfully re-establish extirpated wild populations. A captive breeding program for endangered Sakinaw Lake sockeye salmon was established from 84 adults between 2002 and 2005, just prior to extirpation of the wild population. After several years of absence, sockeye salmon released from captivity returned to spawn in Sakinaw Lake in 2010 and in all years thereafter. Freshwater survival rates of released hatchery fry and naturally produced progeny of reintroduced sockeye salmon have not limited abundance of the reintroduced population. In contrast, marine survival rates for Sakinaw sockeye salmon have been $<1 \%$, a level that precludes population restoration in the absence of supplementation. Genetic diversity commensurate with the number of parental founders has been maintained in captivity. The 517 adult second-generation captive fish that spawned in Sakinaw Lake in 2011 produced a smolt emigration of almost 28,000 juvenile fish with an effective population size of 132. Allelic richness and gene diversity levels in the smolts were similar to those observed in captivity. This indicates genetic contributions from all or most founding parents have been retained both in captivity and in the nascent reintroduced natural population.
\end{abstract}

Keywords: sockeye salmon; captive breeding; survival; reintroduction; genetic diversity 


\section{Introduction}

Biodiversity in salmonid species is maintained by their metapopulation structure, in which local adaptation to wild environments occurs in spite of gene flow among breeding units occupying the same or different watersheds [1]. Maintenance of the complex intraspecific structure is believed to be adaptive and necessary for optimal production and stable abundances [2,3] and legislation requiring the conservation of intraspecific genetic diversity exists in both the United States [4,5] and Canada [6]. Maintenance of genetic diversity in the natural environment was also a cornerstone of the Wild Salmon Policy implemented for Canadian Pacific salmon management [7].

Captive breeding can be used to re-establish a natural population that is briefly extirpated from its natural environment, albeit generally with an associated reduction in genetic diversity compared with the original wild population [8]. The reduction in diversity due to a small number of potentially related founders and an increase in inbreeding during captivity may be exacerbated upon reintroduction to the wild, while natural population size remains small [9]. Success of natural population recovery will depend on numerous environmental and genetic factors which are expected to influence fitness of individuals in the nascent wild population [10]. For salmon, captive breeding has been successful in maintaining the endangered Redfish Lake sockeye salmon population over a twenty year period, but the population is still receiving hatchery supplementation [11]. Similarly, all three federal captive breeding programs established for endangered salmon populations in Canada (Inner Bay of Fundy Atlantic salmon, Cultus Lake and Sakinaw Lake sockeye salmon) are ongoing [12-15].

Genetic factors of concern during captive rearing include the small amount of genetic diversity remaining in the depleted natural population with which to establish the captive program, additional loss of diversity and inbreeding in captivity, and domestication, the adaptive alteration of the population conditioned by differential survival of genotypes in the hatchery environment [16]. Little remedy exists for the small amount of genetic diversity remaining at the inception of captive breeding population since captive breeding generally represents the approach of "last resort" for salmon [17,18]; one strategy is to incorporate genetic material from all or as many extant individuals as possible [19]. Avoiding ongoing diversity loss and minimization of inbreeding requires some degree of pedigree maintenance or breeding design based on minimum kinship analysis [12,19]. Reduction of domestication may benefit from equalization of family contributions to the brood animals each generation [20] but minimization of the duration (number of generations) of captive breeding provides the most certain means of limitation [21].

Ongoing supplementation of a nascent wild population with captively-bred individuals may stabilize abundance and minimize inbreeding in early generations of natural population recovery, but delay re-adaptation to the wild environment during natural population recovery [22,23]. Salmonid domestication has both environmental and genetic components [24] and the reduced reproductive success of captive individuals in the wild environment may persist past the first generation of natural spawning [25]. Realistic accounting for reduced fitness of captive salmon in the wild environment in salmonid population viability analysis indicated that the release of captively-bred individuals into rebuilding wild populations after four to six generations of captivity was as likely to prevent as to facilitate wild population recovery [13]. Practical consideration of the cost of captive rearing for salmonids and the expected increasing number of populations of conservation concern [17,26] also 
impose limitations on the use and duration of such programs. Nevertheless, captive breeding programs have been implemented for a few salmonid populations in danger of extirpation in North America, including the Sakinaw Lake sockeye salmon population.

The potential for extirpation of Sakinaw Lake sockeye salmon was documented in 2002, after the population had been in decline for two decades [27]. The collapse of the adult return migration continued and within short order the population was designated "endangered" by COSEWIC, the Committee on the Status of Endangered Wildlife in Canada [28]. The population abundance had declined from an average of 5000 between 1947 and 1987, to 1000 between 1988 and 1992, to <200 until 1996 and <50 until 2001 [28]. A draft recovery strategy for the population was developed in anticipation of a federal government listing under the Species at Risk Act (SARA) list, which would have dictated legal protection of the population as well as implementation of the recovery plan [6]. The recovery plan indicated that the population would become extinct without "immediate intervention and protection of the remnant population". In 2005, the Canadian government decided to not list Sakinaw sockeye salmon under SARA but expressed a commitment to protect and rebuild the population. Subsequently, the recovery team was disbanded and the recovery plan abandoned. Nevertheless, the federal government has supported activities from the draft plan on a limited basis since that time.

Many factors had been identified as potentially influential in the rapid decline of the population, including environmental degradation of the freshwater habitat, poor ocean conditions and impediments to lake entry for the adults in the form of a small dam and fishway at the lake outlet [27]. The dam limited adult access to the lake to specific tide conditions and the fishway facilitated human and otter predation during lake entry. Of primary concern, however was the exploitation rate of Sakinaw sockeye salmon in mixed-stock fisheries, which constituted a probable major culprit in the decline [27], but for which there were few data to assess properly.

The Sakinaw population occupies a meromictic lake on the Sechelt peninsula of British Columbia (Figure 1) that, at an elevation of $5 \mathrm{~m}$, is barely above and only a short distance from the Pacific Ocean, to which it drains through a $100 \mathrm{~m}$ creek [27]. The lake consists of a 30-m freshwater lens overlaying saltwater of marine origin, with depths ranging to $140 \mathrm{~m}$. Sakinaw Lake is a highly productive sockeye salmon spawning and nursery lake, with a population characterized by large smolt (juvenile) and small adult size. The Sakinaw Lake sockeye salmon are beach-spawners, utilizing lake shore beaches and fluvial fans for breeding, usually at depths of 3-4 m [27].

Sakinaw Lake sockeye salmon are genetically distinct from other populations [29,30] and are characterized by an early but extended adult return migration and correspondingly long freshwater residence prior to spawning. Small adult size results in both low fecundity and small egg size [27]. Smolts are large and generally emigrate from the lake at one year of age. Distribution of Sakinaw sockeye salmon in the ocean is uncertain, but genetic identification supports the suggestion that, as is typical for sockeye salmon populations from the south coast of British Columbia, Sakinaw juvenile fish migrate northwards as far as the Gulf of Alaska [31]. The primary age of adult return is four years, but smaller numbers return at ages three and five. Identification of adult Sakinaw sockeye salmon on their return migration in recent years indicates that they have returned to the Strait of Georgia through both Johnstone and Juan de Fuca straits (data not shown), although Johnstone Strait is believed to be the historically more important route [27]. 
Figure 1. Location of Sakinaw Lake in southern British Columbia, Canada. Rosewall hatchery on Vancouver Island, where captive breeding of Sakinaw sockeye salmon was conducted, is also shown in inset.

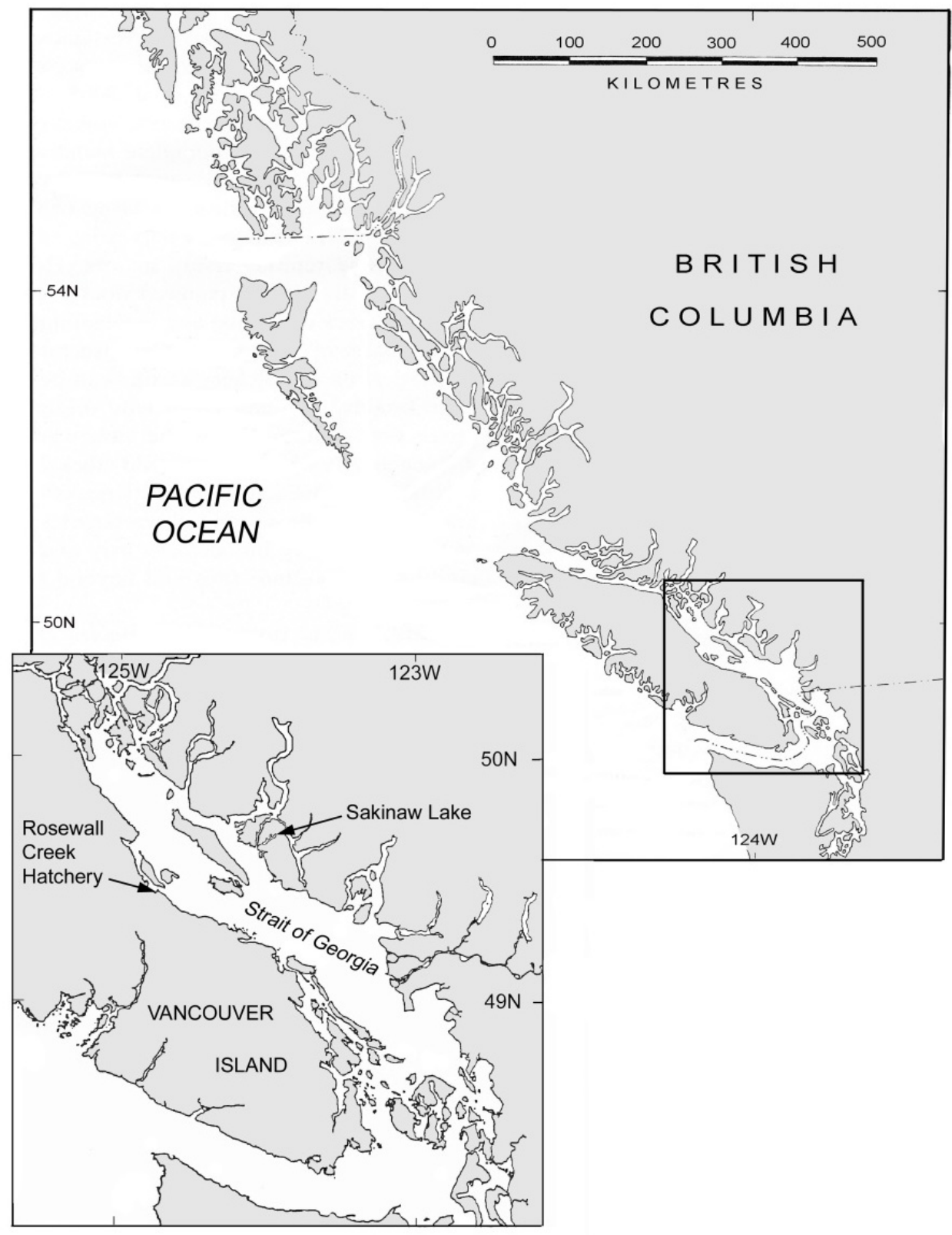

The recovery plan goal for the Sakinaw population was "to stop the decline of the Sakinaw Lake sockeye salmon population and re-establish a self-sustaining, naturally spawning population, ensuring the preservation of the unique biological characteristics of this population." This goal was to be achieved through a set of objectives which included a timeline for population rebuilding based on minimum acceptable annual numbers of naturally-produced adult fish in the wild environment. These were as follows: (1) 2004-2007: Increase the annual number of spawners (including those removed for hatchery broodstock) to no fewer than 500, (2) 2008-2011: Increase the number of naturally produced spawners to no fewer than 500 annually, and (3) 2012-2017: Ensure that by 2017, the mean population abundance in any four year period exceeds 1000 naturally produced spawners, with no fewer than 500 naturally produced spawners in a year. 
Included in the suite of suggested recovery actions was implementation of a captive breeding program. It was assumed that the population would remain extant in the wild environment, albeit initially at low abundance, and that adult returns to Sakinaw Lake during population restoration would be a combination of naturally- and hatchery-spawned individuals. In fact, the wild Sakinaw Lake sockeye salmon population was extirpated between 2006 and 2009, a four-year period in which one or zero adult sockeye salmon was observed entering the lake each year.

The decision to not list the Sakinaw population under SARA annulled implementation of a formal recovery process and the extirpation of the Sakinaw population in 2006 rendered the original recovery objectives unachievable. However, a captive breeding program was established with wild Sakinaw sockeye salmon parental fish spawned between 2002 and 2005 and has continued since. Assessment of adult returns and smolt enumeration at Sakinaw Lake, plus other recommended recovery activities, were also maintained.

In 2010, a small number of adult fish from the captive breeding program returned to Sakinaw Lake and captively-bred adult fish (termed reintroduced) have returned to the Lake in each of the three successive years. In 2010, some of the reintroduced adults were captured and used in hatchery spawning at Sakinaw Lake but made no contribution to the captive breeding program. The juveniles produced were released to Sakinaw Lake. Since 2010, the focus has been to facilitate spawning of reintroduced sockeye salmon adults in the lake; no removals of fish for hatchery spawning have occurred.

Herein we provide population adult and smolt abundance estimates for the Sakinaw population from 2001 to 2013 and analyses of multilocus microsatellite genotypes obtained from available Sakinaw sockeye salmon samples. With the genetic data, we estimate genetic diversity (allelic richness and gene diversity) in, and pairwise genetic distances among, wild fish sampled prior to population extirpation, some parental founders of the captive breeding program, captive brood fish between 2005 and 2011, and reintroduced adult and juvenile Sakinaw sockeye salmon sampled between 2011 and 2013. The genetic data are also used to estimate the genetic effective brood sizes of Sakinaw sockeye salmon sampled over the time course of available samples (1988-2013).

The following criteria were used to evaluate success of captive breeding: (1) the allelic richness and gene diversity of annual captive brood samples remain at or increase from levels observed in parental founder fish as captive fish from different founding groups are interbred in captivity; (2) the genetic distances between pre-extirpation wild fish and reintroduced naturally-spawned Sakinaw sockeye salmon be no greater than between the original wild sample and wild parental founders of the captive breeding program; and (3) the effective sizes of reintroduced Sakinaw sockeye salmon be greater than or equal to the number of founding parents used for the captive program. The results of the study are used in a consideration of the ramifications of maintaining or reducing/eliminating captive breeding for the Sakinaw Lake population.

\section{Experimental Section}

\subsection{Sakinaw Lake Sockeye Salmon Assessment}

The Sakinaw sockeye salmon life cycle can be summarized in terms of the calendar year in which the parental fish spawn (the broodyear, BY) and each of the four succeeding years. In the first year 
after spawning $(B Y+1)$, the juveniles hatch and emerge from the gravel in Sakinaw Lake and in spring of the following year $(\mathrm{BY}+2)$ the vast majority $(>95 \%)$ of juveniles (termed smolts) migrate out of Sakinaw Lake to the ocean. The following three years $(B Y+3,4,5)$ are the years in which adults return to Sakinaw Lake to spawn and die, at ages three to five. In the wild, the primary age of return and maturation is age four with only small numbers of males maturing at age three and rare age five adults of both sexes.

Adult sockeye salmon returning to Sakinaw Lake have most often been enumerated as they pass upstream through the fishway at the lake outlet from mid-June through mid-September. Prior to 2002, estimates of the number of spawning adults were also occasionally derived from either shore or swim-based counts of fish present on spawning beaches in November and December. Since 2002, adult returns were estimated exclusively from the fishway count, continuously recorded by a Avigilon motion-detecting video system, minus any fish collected for hatchery broodstock and known in-lake mortalities due to predation.

The numbers of juvenile sockeye salmon emigrating from Sakinaw Lake between early April and mid-June have been estimated annually since 2003. Smolts were directed through the lake outlet dam into a trap box and counted individually prior to release downstream. As the number of smolts increased, this method became inefficient. In 2013, smolt counts were automated with the use of a VAKI Bioscanner Fish Counter Daily calibrations, counting a known number of fish through the counter, were used to correct automatic counts.

In most BYs, hatchery-reared fry were marked with an adipose fin clip prior to release in the lake and smolts were examined for fin clips during emigration. During BYs 2008-2010 there were zero or one returning wild fish and hatchery-reared fry were not clipped. Thus, all fish returning to Sakinaw Lake in 2012 and 2013 were assumed to be of hatchery origin. Although 16 reintroduced adult sockeye salmon spawned naturally at Sakinaw Lake in 2010, the resulting natural smolts in 2012 were not distinguishable from the unclipped hatchery fry released from BY 2010. Clipping of hatchery fry resumed with the $2011 \mathrm{BY}$.

Relatively large numbers of reintroduced sockeye salmon spawned in Sakinaw Lake in 2011 and the proportion of unclipped smolts two years later was expected to be higher than in previous years. During 2013, either all emigrating smolts encountered or daily subsamples of smolts were examined to determine the proportion of clipped, hatchery-origin smolts. The daily proportions of clipped and unclipped smolts were modeled using a binomial generalized linear model in R [32] and the modelled proportion was used to assign clip status to total daily counts of smolts on subsampled days.

Fresh water survival rate estimates of the Sakinaw Lake wild (prior to 2006) and reintroduced (since 2011) sockeye salmon population, from egg deposition to smolt emigration, were calculated by dividing the estimated number of unclipped smolts by estimated egg deposition on Sakinaw Lake spawning beaches. Egg deposition estimates were obtained by assuming a 1:1 sex ratio among adult fish and using an average fecundity of 2500 eggs per female [27]. For hatchery fry, egg to fry survivals were estimated at Rosewall hatchery as the number of total number of live fry hatched divided by the number of fertilized eggs. Fry to smolt survivals were calculated as number of hatchery smolts emigrating from Sakinaw Lake divided by the number of hatchery fry released. Egg to smolt survivals for hatchery fry were obtained as the products of annual egg to fry and fry to smolt survival estimates. 
Marine survival rates were estimated as adult returns divided by the number of smolts emigrating two years earlier; thus including mortality due to both natural death and harvest. This calculation assumes that the proportion of adults retuning at age three and age five are small and consistent year to year such that there would be only minor and consistent bias in these estimates. Marine survival rates were estimated for wild and hatchery origin sockeye salmon separately.

\subsection{Captive Breeding}

The Sakinaw captive breeding program was established at Rosewall hatchery on Vancouver Island to rear Sakinaw sockeye salmon to maturity in freshwater, breed them and use the resulting juvenile fish for release to the natural environment (supplementation) and ongoing captive breeding. The program was established with progeny of wild Sakinaw sockeye salmon spawned at Ouillet hatchery on Sakinaw Lake in each of three parental BYs (P2002, P2004, P2005). Each year a small number of adult fish was spawned in semi-factorial fashion at Ouillet hatchery and $\leq 3500$ progeny were transferred to Rosewall hatchery for captive rearing the following spring. Remaining juveniles from Ouillet spawning were fin clipped and released to Sakinaw Lake.

The Sakinaw sockeye salmon reared at Rosewall hatchery matured primarily at ages three and four. Age five fish were spawned only in the 2007 BY, when four age five fish (three males and one female) were spawned. Mature fish were first available to spawn at Rosewall in 2005, the final year in which founding parental fish were spawned at Ouillet hatchery. Therefore, for the 2005 BY only, fertilized eggs incubated at Rosewall hatchery were a combination of $F_{1}$ progeny from P2005 spawning at Ouillet hatchery and $F_{2}$ progeny resulting from spawning of P2002 $F_{1}$ fish at Rosewall hatchery. Thereafter, all hatchery spawning took place at Rosewall hatchery (captive breeding 2006-2013), except for the spawning of 13 reintroduced adults at Ouillet hatchery in 2010, the first year in which reintroduced sockeye salmon returned to spawn in Sakinaw Lake.

At Rosewall hatchery, each male and female was spawned with 1-3 mates on a given spawning day; males were often used on two or more spawning days because the male:female ratio was $<1.0$. Juvenile fish retained at Rosewall hatchery each year for future use as captive brood were divided into two or three groups for rearing. All progeny from a given female were placed within a rearing group, so that full-sib crosses could be avoided in future spawning events by selecting mates from alternative groups within an age class, or between age-class groups. Occasionally, the absence of mature fish from more than one group precluded the use of mates from different groups. All progeny resulting from "within-group" matings were released from Rosewall each year; none were retained for future captive breeding. Over time, the number of fish retained for future spawning was standardized to 1,500 annually.

A pedigree of progeny production in Sakinaw sockeye salmon captive breeding from founders spawned in each of the three parental BYs was developed from hatchery records of the number, age, gender and cross design of captive brood between 2005 and 2012. It depicts the overlapping production of age three and four descendants from P2002, P2004 and P2005, and illustrates the progeny filial generations that were interbred over time. 


\subsection{Tissue Sampling for Genetic Analysis}

DNA was extracted from fin or organ tissues preserved in $95 \%$ undenatured ethanol. Wild adult sockeye salmon were sampled in Sakinaw Lake in 1988, as were the wild parental brood fish spawned in P2005 at Ouillet hatchery (Table 1). Parental fish of P2002 and P2004 were not sampled. Throughout captive rearing at Rosewall hatchery, brood fish were sampled opportunistically for future genetic analysis but ongoing analysis of brood samples for pedigree management was not supported. Sample sizes of brood fish at Rosewall varied among years, with all Rosewall brood fish sampled only in 2012 (Table 1).

Table 1. Sample sizes (n) of Sakinaw Lake sockeye salmon used for genetic analysis in this study. Fish were sampled from the wild population prior to extirpation, from P2005 founder parents of the captive breeding program, from captive parental fish at Rosewall hatchery, and from reintroduced adult and juvenile Sakinaw sockeye salmon test fisheries or Sakinaw Lake.

\begin{tabular}{ccc}
\hline Sample Location and Date & $\mathbf{n}$ & Life Stage \\
\hline \multicolumn{3}{c}{ Wild Sakinaw Lake } \\
1988 & 81 & adult \\
Parental 2005 & 25 & adult \\
\hline \multicolumn{3}{c}{ Rosewall Captive Brood } \\
2005 & 196 & adult \\
2006 & 84 & adult \\
2010 & 224 & adult \\
2011 & 429 & adult \\
& 1062 & adult \\
2011 fishery and lake & 25 & adult \\
2012 fishery and lake & 15 & adult \\
2013 fishway fence & 110 & hatchery smolt \\
2013 fishway fence & 161 & natural smolt \\
2013 smolts (all) & 271 & smolt \\
\hline
\end{tabular}

Starting in 2011, small samples of reintroduced adult Sakinaw sockeye salmon caught in marine test fisheries or sampled after spawning in Sakinaw Lake were also analyzed. In 2013, samples of clipped (from 2011 BY hatchery releases) and unclipped (from natural spawning of reintroduced adult returns in 2011) emigrating smolts were also analyzed. The smolt samples, collected throughout the spring 2013 smolt emigration, constituted the largest samples of reintroduced Sakinaw sockeye salmon obtained.

\subsection{Genetic Analysis}

All genetic analyses on Sakinaw Lake sockeye salmon tissues were conducted on genotypes from 14 polymorphic unlinked microsatellite loci [33]. The loci were Ots2, Ots3 [34], Ots100, Ots103, Ots107, Ots108 [35,36], Oki1a, Oki1b, Oki6, Oki10, Oki16, Oki29 [37], One8 [38] and Omy77 [39]. Samples scored for less than 10 loci were excluded. Multilocus genotypes were obtained for samples indicated in Table 1. Additionally, genotypes of the P2002 founder parents, not obtained from tissue 
samples, were "reconstructed" from their sampled progeny at Rosewall hatchery, sorted into family groups by maximum likelihood analysis (described below).

Genetic diversity in Sakinaw Lake sockeye salmon was assessed using allelic richness $\left(A_{R}\right)$ standardized to a sample size of 70 fish, gene diversity $\left(\mathrm{H}_{\mathrm{E}}\right)$ and pairwise $\mathrm{F}_{\mathrm{ST}}$ values calculated for samples using FSTAT [40]. Neighbour-joining dendrograms depicting sample relationships were constructed based on pairwise $F_{\text {ST }}$ values using SplitsTree [41]. The small numbers of fish spawned in each of founding BYs was expected to be reflected in significant allele frequency variation and genetic distances among the parental groups, and between them and the sample of wild Sakinaw fish. Additionally, the founder effects were expected to result in low $A_{R}$ and $H_{E}$ early in the captive brood program, but to be mitigated by commingling of parental contributions in captivity over time.

The maximum likelihood method of COLONY [42,43] was used to determine family structure in three groups of progeny that arose from individual spawning events throughout the study. In each case, the likely family structure of sampled progeny was determined by assigning them to supplied parental genotypes where a genotypic match was available and to "phantom" or reconstructed parents in the absence of sampled matching parental genotypes.

COLONY analysis consisted of the simultaneous examination of progeny genotypes (a group-likelihood approach) in order to partition them into families of variable size based on Mendelian inheritance of alleles at unlinked loci. The program was run assuming parental polygamy for both sexes (the known mating design) and with both types of genotyping error set at 0.01 for all loci. Error types are class I (allelic dropout) and class II (all other "errors" including miscalling of alleles, PCR artifacts and mutation). The assigned error rate was considered an upper bound for plausible values given that error rates in repeated genotyping of samples from this species in our laboratory are almost an order of magnitude lower. Re-genotyping does not reveal all sources of Mendelian "error" (e.g., mutation, some PCR artifacts).

Adult age three and four fish that matured at Rosewall hatchery in 2005 and 2006 were all progeny of the P2002 founders spawned at Ouillet hatchery. The crosses made with each parental fish (5 females and 9 males) were recorded, indicating that a total of 17 different crosses produced viable progeny. No parental DNA samples were collected but all 280 of their progeny spawned in captivity were sampled. Progeny genotypes were assigned to family groups using COLONY in the absence of parental genotypes and with the assumption of polygamy for male and female parents. The variances in progeny numbers were determined from assigned family structure and used to estimate $\mathrm{N}_{\mathrm{b}}$, the variance effective size of P2002, according to the standard relationship: $\mathrm{N}_{\mathrm{b}}=\left(\Sigma \mathrm{N}_{\mathrm{ij}}\right)^{2} / \Sigma \mathrm{N}_{\mathrm{ij}}{ }^{2}$ where $\mathrm{N}_{\mathrm{ij}}$ are the numbers of progeny produced by male and female parents.

Family structure among adult progeny of the 2008 captive brood parents at Rosewall hatchery was also examined with COLONY. Captive juveniles produced from the 2008 BY were progeny of 780 parents used to produce almost 1,000 individual matings. Of approximately 1,500 juvenile fish retained from this cohort for captive rearing, 818 were spawned in 2011 at age 3 and 299 were spawned at age four in 2012. In 2011, 301 age three fish (37\% of total age three spawners) and in 2012 all age four brood fish were sampled for genetic analysis. The 600 genotypes obtained were partitioned to families using COLONY with no parental genotypes provided.

Finally, the Rosewall captive brood of 2011 were parents of the hatchery smolts sampled during the spring 2013 smolt emigration from Sakinaw Lake. Approximately 40\% of the 1032 captive brood fish 
spawned at Rosewall hatchery in 2011 were sampled for genetic analysis; and generally both parents involved in crosses were sampled or not sampled. Parental genotypes were supplied in a COLONY analysis of the smolt genotypes, with the parental sampling rate set at $40 \%$.

Genetically effective sizes for spawning groups of sockeye salmon $\left(\mathrm{N}_{\mathrm{b}}\right)$, based on pairwise linkage disequilibrium of alleles between loci, were estimated with the program LDNe [44]. $\mathrm{N}_{\mathrm{b}}$ was estimated with the assumption of random mating and based on a minimum allele frequency of 0.02 . In Pacific salmon, the total effective size of a population $\left(\mathrm{N}_{e}\right)$ is the sum of the effective number of breeders $\left(\mathrm{N}_{\mathrm{b}}\right)$ in each year of the average generation time [45]. As with genetic diversity measures, low but increasing $\mathrm{N}_{\mathrm{b}}$ estimates in adult captive brood fish were expected if the breeding program successfully minimized genetic drift and integrated the genetic contributions of the small parental founding groups. The linkage-based $\mathrm{N}_{\mathrm{b}}$ estimates obtained for captive progeny of the P2002 spawned in 2005 and 2006 were compared to the variance based estimate based on family assignment.

$\mathrm{N}_{\mathrm{b}}$ estimates for the 2013 smolt samples were used to assess retention of parental contributions in hatchery spawning (hatchery smolts) and in natural spawning of reintroduced sockeye salmon in 2011 (natural smolts). The $\mathrm{N}_{\mathrm{b}}$ of hatchery smolts sampled in 2013 was also compared with those estimated for captive brood samples. This was done to determine if there was a higher $\mathrm{N}_{\mathrm{b}}$ value in smolts released from the hatchery than in smolts retained in the hatchery and subsequently spawned as captive brood fish. Each year, the number of smolts retained in the captive program was small compared to the number released to the natural environment and was likely to consist of fish drawn from fewer families..

Admixture of genes contributed by parental founder groups was estimated from microsatellite data using the LEADMIX (likelihood estimation of admixture) program [46]. The program provided both the maximum likelihood estimates and moment estimates calculated according to Roberts et al. [47]. The distinctive allele frequencies (founder effects) of the parental groups enabled estimation of the genetic contributions of each parental group to the hatchery and natural smolts sampled in 2013. Genotypes were available for the P2005 and P2002 (reconstructed) founder parents, but not for 2004 $\mathrm{BY}$ parents. Instead, age four fish that matured at Rosewall in the $2011 \mathrm{BY}$, primarily $\mathrm{F}_{2}$ fish from P2004 spawning, were used to provide proxy allele frequencies.

The admixture analysis is based on a model in which two or more source populations derived from a common ancestral population become admixed (hybridized) after secondary contact is re-established [46]. Changes in allele frequencies through drift occur both in the source populations after their divergence from the ancestral population and in the admixed population derived from the source populations. The proportions of genes contributed by the source populations (and their $95 \%$ confidence intervals) are estimated based on an assigned minimum level of drift (0.00001 herein), with mutation ignored. Whereas the ML estimates may provide the most accurate estimates of contributions, the broader confidence limits of the moment estimators (provided) are more conservative than the very narrow confidence interval associated with the ML estimates (not provided).

\section{Results}

\subsection{Sakinaw Lake Sockeye Salmon Assessment}

The abundance of wild spawning Sakinaw Lake sockeye salmon adults averaged 35 (range 3 to 62) after broodstock removals in the six years prior to extirpation of the wild population in 2006 (Table 2). 
Between 2006 and 2009, inclusive, zero or one sockeye salmon returned to Sakinaw Lake and no spawning occurred at Ouillet hatchery. Captively-bred sockeye salmon from the Rosewall captive breeding program began returning to Sakinaw Lake in 2010, with the return of 29 adult fish. Thirteen of these were removed for Ouillet hatchery spawning, the remainder spawned naturally in the lake (Table 2). Since that year, no reintroduced adults have been removed for hatchery breeding. Between 2010 and 2013, inclusive, the estimated numbers of captively-bred adult fish that returned to the lake and survived to spawning has averaged 228 (range 16 to 517; Table 2).

Table 2. Numbers of adult sockeye salmon that returned to Sakinaw Lake each broodyear (BY), including those removed as male (M) and female (F) Ouillet hatchery broodstock, and the number estimated to spawn naturally in Sakinaw Lake. The numbers of Ouillet and Rosewall hatchery fry (in thousands) released into the lake in the following year $(B Y+1)$, and the numbers of natural and hatchery smolts (in thousands) emigrating from the lake after two years $(B Y+2)$ are also shown. Zeros indicate no fish; dashes indicate no data. Unk indicates an unknown number of natural smolts were included in the hatchery smolt total because there was no clipping of hatchery juveniles from that year. Numbers in parentheses indicate wild Sakinaw parents from which fertilized eggs were used to found the captive breeding program at Rosewall hatchery.

\begin{tabular}{|c|c|c|c|c|c|c|c|c|c|c|}
\hline \multicolumn{5}{|c|}{ Adult (BY) } & \multicolumn{3}{|c|}{ Fry $(B Y+1) \times 1000$} & \multicolumn{3}{|c|}{ Smolt $(B Y+2) \times 1000$} \\
\hline BY & Return & $\begin{array}{c}\text { Lake } \\
\text { Spawners }\end{array}$ & $\begin{array}{r}\text { Hatcher } \\
\text { F }\end{array}$ & $\begin{array}{l}\text { Removal } \\
\text { I }\end{array}$ & Ouill & $\mathbf{R W}$ & Total & Nat & Hat & Total \\
\hline \multicolumn{11}{|c|}{ Wild } \\
\hline 2000 & 122 & - & 10 & 9 & 15.0 & 0 & 15.0 & - & - & - \\
\hline 2001 & 87 & 58 & 15 & 14 & 31.9 & 0 & 31.9 & 4.3 & 8.1 & 12.4 \\
\hline 2002 & 78 & 62 & $6(5)$ & $10(9)$ & 2.8 & 0 & 2.8 & 0.103 & 0.039 & 0.142 \\
\hline 2003 & 3 & 3 & 0 & 0 & 0 & 0 & 0 & 0.011 & 0.002 & 0.013 \\
\hline 2004 & 99 & 37 & $31(28)$ & $31(28)$ & 25.9 & 0 & 25.9 & 2.9 & 8.4 & 11.3 \\
\hline 2005 & 28 & 14 & $6(6)$ & $8(8)$ & 7.6 & 87.9 & 95.5 & 0.272 & 3.7 & 4.0 \\
\hline \multicolumn{11}{|c|}{ Extirpated } \\
\hline 2006 & 1 & 1 & 0 & 0 & 0 & 84.6 & 84.6 & 0 & 12.2 & 12.2 \\
\hline 2007 & 0 & 0 & 0 & 0 & 0 & 420.8 & 420.8 & 0 & 62.6 & 62.6 \\
\hline 2008 & 0 & 0 & 0 & 0 & 0 & 726.4 & 726.4 & 0 & 69.9 & 69.9 \\
\hline 2009 & 1 & 1 & 0 & 0 & 0 & 329.4 & 329.4 & 0 & 32.9 & 32.9 \\
\hline \multicolumn{11}{|c|}{ Reintroduced } \\
\hline 2010 & 29 & 16 & 4 & 9 & 5.1 & 1368.7 & 1373.8 & unk & 162.9 & 162.9 \\
\hline 2011 & 554 & 517 & 0 & 0 & 0 & 963.3 & 963.3 & 28.0 & 224.6 & 252.5 \\
\hline 2012 & 244 & 238 & 0 & 0 & 0 & 856.2 & 856.2 & - & - & - \\
\hline 2013 & 144 & 142 & 0 & 0 & 0 & - & - & - & - & - \\
\hline
\end{tabular}

Total hatchery fry releases from BYs 2000 to 2012 averaged 397,650 (range 0 to $1.37 \mathrm{M}$ ). From 2005 BY onwards, fry production was dominated by Rosewall hatchery captive brood and averaged 606,250 (range 84,600 to $1.37 \mathrm{M}$; Table 2). Even with Ouillet hatchery fry supplementation of the lake, the total numbers of emigrating smolts in BYs 2000-2004 were low (Table 2). With captive breeding, the numbers of smolts emigrating from the lake increased by an order of magnitude 
from an average of approximately 6000 from BYs 2001-2004 to over 85,000 from BYs 2005-2011. Wild smolts, products of adult spawning on beaches in Sakinaw Lake in BYs 2001 to 2005 prior to extirpation, averaged 1529 (range 11 to 4334; Table 2). The 517 reintroduced sockeye salmon that spawned on traditional spawning beaches in Sakinaw Lake in 2011 produced 27,960 natural smolts in 2013 (Table 2).

Freshwater survival, measured as egg to smolt survival for juveniles produced by lake spawners and as fertilized egg to smolt survival for hatchery fry, has been monitored since 2001 (Table 3). Survival of wild juveniles averaged $2.9 \%$ (range $0.1 \%$ to $6.3 \%$ ) prior to extirpation of the wild population and has been measured once for natural juveniles since reintroduction at $4.3 \%$. Freshwater survival rates for released hatchery fry, from egg to smolt, have averaged $11.5 \%$ (range $3.0 \%$ to $21.1 \%$; Table 3 ). If the BY 2011 survival of natural fry (from reintroduced parents) to smolt was the same as hatchery fry to smolt survival, then the natural egg to fry survival rate in the lake must have been $18.5 \%$ (i.e., $0.233 \times 0.185=0.043$ ).

Table 3. Estimates of fresh water and marine survival by broodyear for natural and hatchery Sakinaw Lake sockeye salmon. Estimates are not available (n/a) for broodyears where the life cycle is incomplete or assessment information to allow estimates were lacking and were not calculated (-) when $\leq 1$ adult spawned naturally.

\begin{tabular}{cccccccccccc}
\hline Life History Stage & $\mathbf{2 0 0 1}$ & $\mathbf{2 0 0 2}$ & $\mathbf{2 0 0 3}$ & $\mathbf{2 0 0 4}$ & $\mathbf{2 0 0 5}$ & $\mathbf{2 0 0 6}$ & $\mathbf{2 0 0 7}$ & $\mathbf{2 0 0 8}$ & $\mathbf{2 0 0 9}$ & $\mathbf{2 0 1 0}$ & $\mathbf{2 0 1 1}$ \\
\hline Freshwater Survival (\%) & & & & & & & & & & & \\
Natural (egg to smolt) & 6.0 & 0.1 & 0.3 & 6.3 & 1.6 & - & - & - & - & $\mathrm{n} / \mathrm{a}$ & 4.3 \\
Hatchery (egg to fry) & - & - & - & - & 77.5 & 84.8 & 96.3 & 97.8 & 86.8 & 97.6 & 90.4 \\
Hatchery (fry to smolt) & 25.3 & 1.4 & - & 32.2 & 3.9 & 14.4 & 14.9 & 9.6 & 10.0 & 11.9 & 23.3 \\
Hatchery (egg to smolt) & - & - & - & - & 3.0 & 12.2 & 14.3 & 9.4 & 8.7 & 11.6 & 21.1 \\
\hline Marine Survival (\%) & & & & & & & & & & & \\
$\quad$ Natural & 0.5 & 1.0 & 0.0 & 0.0 & 0.0 & - & - & - & - & $\mathrm{n} / \mathrm{a}$ & $\mathrm{n} / \mathrm{a}$ \\
$\quad$ Hatchery & 0.1 & 0.0 & 0.0 & 0.0 & 0.0 & 0.1 & 0.8 & 0.3 & 0.3 & $\mathrm{n} / \mathrm{a}$ & $\mathrm{n} / \mathrm{a}$ \\
\hline
\end{tabular}

Marine survival rates have been very low for both wild and hatchery sockeye salmon in Sakinaw Lake (Table 3). Marine survival of wild fish has averaged $0.3 \%$ (range 0 to $1.0 \%$ ), only marginally better than the $0.2 \%$ (range 0 to $0.8 \%$ ) survival of hatchery reared fish since BY 2001.

\subsection{Captive Breeding}

Small numbers of wild Sakinaw Lake sockeye salmon spawned at Ouillet hatchery between 2000 and 2005 provided $F_{1}$ juveniles that were released to Sakinaw Lake (Table 2). In P2002, P2004 and P2005, the Sakinaw adult fish spawned at Ouillet hatchery also provided the $F_{1}$ progeny used to establish the Sakinaw sockeye salmon captive breeding program at Rosewall hatchery. From each of the BYs, respectively, 3462, 1500 and 2200 fertilized eggs or juvenile fish were transferred to Rosewall hatchery and reared in captivity. The dual age of maturation and husbandry improvements in the captive breeding program led to increased numbers of captive brood fish over time (Table 4, Figure 2). Starting in 2008, age three and four fish both matured in the captive brood annually, leading to complete commingling of the parental lineages by BYs 2010-2012 (Table 4, Figure 2). 
Table 4. Sakinaw Lake sockeye salmon captive brood numbers by age and gender for broodyears (BY) 2005 to 2012 at Rosewall hatchery. Descendants of the three parental founder groups are indicated by filial generation for each age group in each of the captive BYs. In the $2007 \mathrm{BY}$, four age 5 adults $\left(2002 \mathrm{~F}_{1}\right)$ were also spawned (not shown).

\begin{tabular}{|c|c|c|c|c|c|c|c|c|}
\hline \multirow{2}{*}{$\begin{array}{c}\text { Captive } \\
\text { BY }\end{array}$} & \multicolumn{2}{|c|}{ Age 3 Brood } & \multirow{2}{*}{$\begin{array}{c}\text { Filial } \\
\text { Generation }\end{array}$} & \multicolumn{2}{|c|}{ Age 4 Brood } & \multirow{2}{*}{$\begin{array}{c}\text { Filial } \\
\text { Generation }\end{array}$} & \multirow{2}{*}{$\begin{array}{c}\text { Brood } \\
\mathbf{N}\end{array}$} & \multirow{2}{*}{ Matings } \\
\hline & Males & Females & & Males & Females & & & \\
\hline 2005 & 89 & 107 & $2002 F_{1}$ & 0 & 0 & - & 196 & 253 \\
\hline 2006 & 0 & 0 & - & 31 & 53 & $2002 F_{1}$ & 84 & 114 \\
\hline 2007 & 158 & 325 & $2004 \mathrm{~F}_{1}$ & 0 & 0 & - & 483 & 712 \\
\hline 2008 & 222 & 385 & $2002 \mathrm{~F}_{2}, 2005 \mathrm{~F}_{1}$ & 84 & 89 & $2004 F_{1}$ & 780 & 934 \\
\hline 2009 & 69 & 184 & $2002 \mathrm{~F}_{2}$ & 95 & 59 & $2002 \mathrm{~F}_{2}, 2005 \mathrm{~F}_{1}$ & 407 & 482 \\
\hline 2010 & 133 & 379 & $2004 \mathrm{~F}_{2}$ & 160 & 423 & $2002 \mathrm{~F}_{2}$ & 1095 & 1568 \\
\hline 2011 & 288 & 530 & $\begin{array}{c}2002 \mathrm{~F}_{3}, 2005 \mathrm{~F}_{2} \\
2004 \mathrm{~F}_{2}\end{array}$ & 117 & 97 & $2004 \mathrm{~F}_{2}$ & 1032 & 1248 \\
\hline 2012 & 264 & 499 & $2002 \mathrm{~F}_{3}, 2005 \mathrm{~F}_{2}$ & 139 & 160 & $\begin{array}{c}2002 \mathrm{~F}_{3}, 2004 \mathrm{~F}_{2}, \\
2005 \mathrm{~F}_{2}\end{array}$ & 1062 & 1318 \\
\hline
\end{tabular}

Figure 2. Pedigree showing Sakinaw sockeye salmon parental $\left(\mathrm{P}_{1}\right)$ fish spawned at Ouillet hatchery and filial $\left(\mathrm{F}_{1}-\mathrm{F}_{4}\right)$ groups spawned in the captive breeding program at Rosewall hatchery. Fish matured at ages three ( 3 yo) and four ( 4 yo). Fish were reared in pooled groups at Rosewall hatchery from each broodyear (BY) so that individual identity was not maintained. Spawning was among available fish from all three parental lineages each year although only crosses within lineages are depicted.

2002 BY

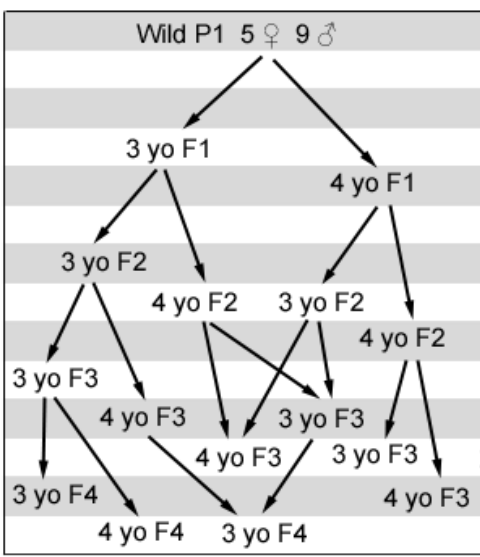

2004 BY

2002

\subsection{Genetic Variation in Wild, Captive and Reintroduced Sakinaw Sockeye Salmon}

Microsatellite allele frequencies differed significantly between the two smaller founder groups (P2002 and P2005) and the larger P2004 group (both $p<0.05$ ). The P2002 and P2004 allele frequencies differed significantly $(p<0.05)$ from those of the 1988 wild Sakinaw sample (Table 5). Allele frequencies in each of the annual captive broods spawned at Rosewall hatchery also differed significantly from the wild sample (all $p<0.05$ ). The 2005 and 2006 captive broods, consisting entirely of progeny from P2002 parents, were highly distinctive (Figure 3a) and characterized by low 
values of $A_{R}$ (Table 6, Figure 4). In contrast, the captive broods between 2010 and 2012 were more similar to wild Sakinaw sockeye salmon prior to extirpation (Figure $3 a$ ) and had higher levels of $A_{R}$ (Table 6), reflecting contributions from all three parental founder groups. Both the hatchery and natural smolts sampled in 2013 had $A_{R}$ values similar to those observed in later captive broods (Table 6, Figure 4).

Table 5. Pairwise $F_{S T}$ values between wild and reintroduced Sakinaw sockeye salmon are given above the diagonal. Wild founders of the captive breeding program were represented by parental genotypes (P2002 and P2005) or $\mathrm{F}_{2}$ genotypes (P2004). Reintroduced fish included both adult and smolts; smolts originated from spawning at Rosewall hatchery (Hat) or in Sakinaw Lake (Nat). Significant (asterisk) and non-significant (NS) allele frequency differentiation is indicated below the diagonal.

\begin{tabular}{ccccccccc}
\hline Sample & $\mathbf{1 9 8 8}$ & P2002 & P2004 & P2005 & $\begin{array}{c}\text { 2011 } \\
\text { Adult }\end{array}$ & $\begin{array}{c}\mathbf{2 0 1 2} \\
\text { Adult }\end{array}$ & $\begin{array}{c}\text { Hat } \\
\text { Smolt }\end{array}$ & $\begin{array}{c}\text { Nat } \\
\text { Smolt }\end{array}$ \\
\hline Wild & & & & & & & & \\
1988 & - & 0.026 & 0.023 & 0.004 & 0.016 & 0.017 & 0.015 & 0.019 \\
$\begin{array}{c}\text { Founders } \\
\text { P2002 }\end{array}$ & $*$ & - & 0.031 & 0.014 & 0.032 & 0.022 & 0.040 & 0.004 \\
P2004 & $*$ & $*$ & - & 0.021 & 0.005 & 0.017 & 0.012 & 0.019 \\
P2005 & NS & NS & $*$ & - & 0.017 & 0.000 & 0.000 & 0.012 \\
Reintroduced & & & & & & & & \\
2011 adult & $*$ & $*$ & NS & NS & - & 0.021 & 0.010 & 0.010 \\
2012 adult & $*$ & $*$ & $*$ & NS & $*$ & - & 0.001 & 0.014 \\
Hatchery smolt & $*$ & $*$ & $*$ & NS & $*$ & NS & - & 0.016 \\
Natural smolt & $*$ & $*$ & $*$ & $*$ & $*$ & $*$ & $*$ & - \\
\hline
\end{tabular}

Table 6. Sample size $(n)$, allelic richness $\left(A_{R}\right)$, expected $\left(H_{E}\right)$ and observed $\left(H_{O}\right)$ heterozygosity, and effective number of breeders $\left(\mathrm{N}_{\mathrm{b}}\right)$ for wild, captive and reintroduced Sakinaw sockeye salmon. The $95 \%$ confidence limits of $\mathrm{N}_{\mathrm{b}}$ estimates are given.

\begin{tabular}{cccccccc}
\hline Sample & $\mathbf{n}$ & $\mathbf{A}_{\mathbf{R}}$ & $\mathbf{H}_{\mathbf{E}}$ & $\mathbf{H}_{\mathbf{O}}$ & $\mathbf{N}_{\mathbf{b}}$ & Lower Limit & Upper Limit \\
\hline $\begin{array}{c}\text { Wild Sakinaw Lake } \\
\text { 1988 }\end{array}$ & 81 & 8.4 & 0.66 & 0.67 & 559 & 229 & $\infty$ \\
$\begin{array}{c}\text { Captive BY } \\
\text { 2005 }\end{array}$ & 196 & 5.7 & 0.65 & 0.68 & 12 & 10 & 13 \\
2006 & 84 & 5.6 & 0.61 & 0.64 & 9 & 9 & 12 \\
2010 & 224 & 6.6 & 0.62 & 0.62 & 20 & 20 & 24 \\
2011 & 429 & 7.0 & 0.64 & 0.65 & 87 & 78 & 97 \\
2012 & 1,062 & 6.9 & 0.63 & 0.64 & 58 & 52 & 65 \\
Reintroduced Sakinaw Lake & & & & & & & \\
2011 adult returns & 25 & - & 0.63 & 0.62 & 32 & 24 & 47 \\
2012 adult returns & 15 & - & 0.64 & 0.66 & 65 & 27 & $\infty$ \\
2013 smolts (hatchery) & 110 & 6.7 & 0.64 & 0.64 & 207 & 144 & 342 \\
2013 smolts (natural) & 161 & 6.9 & 0.64 & 0.65 & 132 & 106 & 170 \\
2013 smolts (all) & 271 & 7.1 & 0.64 & 0.65 & 152 & 125 & 187 \\
\hline
\end{tabular}


In contrast to AR, gene diversity (expected heterozygosity) did not differ between the wild Sakinaw sockeye sampled in 1988 and the re-introduced fish sampled between 2011 and 2013. Expected $\left(\mathrm{H}_{\mathrm{E}}\right)$ and observed heterozygosity $\left(\mathrm{H}_{\mathrm{O}}\right)$ levels did not differ in the wild Sakinaw sockeye salmon sampled in 1988. Similarly, the re-introduced Sakinaw sockeye sampled between 2011 and 2013 tended to be in Hardy-Weinberg equilibrium (Table 6). $\mathrm{H}_{\mathrm{O}}$ values tended to exceed $\mathrm{H}_{\mathrm{E}}$ values in captive brood samples due to family structure in the captive cohorts, especially in the 2005 and 2006 BYs.

The small number of reintroduced adult fish sampled upon return to Sakinaw Lake in 2011 were similar $(p>0.05)$ to the P2004 lineage, but showed little genetic similarity to those of P2002 or P2005 (Table 5, Figure 3b). In 2012, the small sample of reintroduced adults from Sakinaw Lake was most genetically similar to the P2005 lineage (Table 5, Figure 3b).

Figure 3. Neighbour-joining dendrograms of pairwise $F_{S T}$ values among wild, captive and reintroduced Sakinaw Lake sockeye salmon. (a) Relationships among the wild 1988 Sakinaw adults, the three wild parental founding groups for the captive breeding program and several BYs of captive breeders at Rosewall hatchery. (b) Relationships among the wild 1988 Sakinaw adults, the three wild parental founding groups for the captive breeding program, the reintroduced adult returns of 2011 and 2012 and the hatchery and natural smolts of 2013.

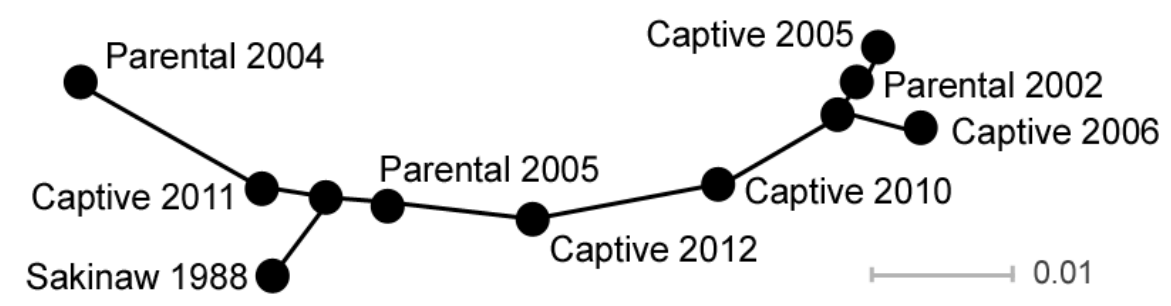

(a)

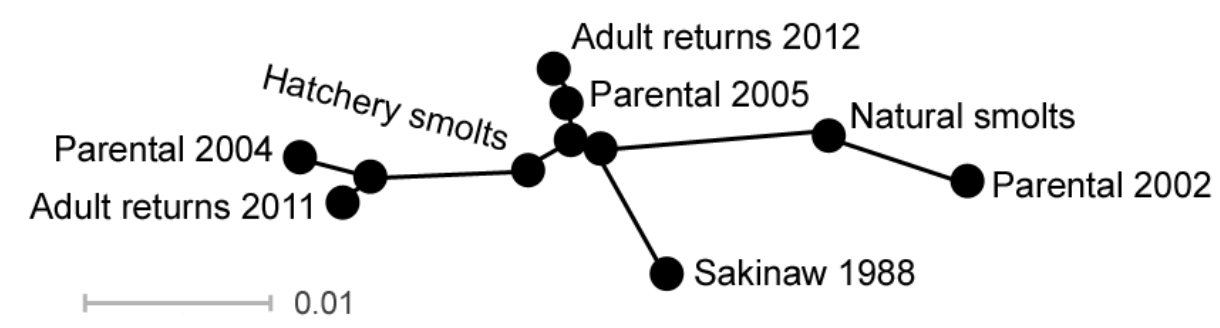

(b)

Allele frequencies estimated from the natural smolts of 2013 may have been more representative of the total 2011 adult return to Sakinaw Lake than those estimated from the small parent sample. The smolts were more genetically similar to the P2002 and P2005 lineages than were the sampled adults (Table 5, Figure 3b). This may indicate that the 517 reintroduced adults that spawned in Sakinaw Lake in 2011 included some proportion of age three fish (from the captive brood of 2008), although this was not indicated by allele frequencies estimated from the small parent sample. Allele frequencies of the 2013 natural smolts were significantly different from those of the 1988 wild Sakinaw sockeye salmon and all parental founding groups. However, the genetic distance between the natural smolts and 1988 wild Sakinaw sample (0.019) was not greater than those between the parental founder groups and the wild sample (0.004-0.026) (Table 5). 
The 2013 hatchery smolts were genetically dissimilar to the natural smolts and more similar to the P2002 lineage than were the natural smolts (Figure 3b). This reflected their admixed origin as they were produced by the 2011 captive brood at Rosewall hatchery (Table 4).

\subsection{Family Structure in Sakinaw Sockeye Salmon Captive Brood and Hatchery Smolts}

The 280 captive fish spawned at Rosewall in 2005 and 2006 were $F_{1}$ progeny of five parental females and nine males in P2002. Assignment of the $\mathrm{F}_{1}$ to families on the basis of genetic relationships among the progeny themselves produced a family structure consistent with the hatchery spawning records (Table 7) and enabled genotypic reconstruction for the 14 parental spawners. Only one recorded cross out of 17 (female 4 with male 4) produced no progeny that survived until maturity, according to the family structure provided by progeny genotype analysis. All parents contributed progeny that were subsequently spawned, although the contributions were unequal. $\mathrm{N}_{\mathrm{b}}$ of the P2002 founders estimated from variance in progeny production among founders was 8.9.

Table 7. Mating structure of wild Sakinaw Lake sockeye salmon parents in P2002 according to hatchery records and numbers of $F_{1}$ progeny assigned to parents by maximum likelihood analysis of progeny genotypes. The progeny were reared in the captive breeding program and spawned at Rosewall hatchery in 2005 and 2006.

\begin{tabular}{cccc}
\hline \multirow{2}{*}{ Spawn Date } & \multicolumn{2}{c}{ Parents } & \multirow{2}{*}{ Progeny N } \\
\cline { 2 - 3 } Nov 11 & 0 & 9 & \\
& 1 & 1 & 70 \\
& 1 & 2 & 10 \\
& 2 & 1 & 10 \\
& 2 & 2 & 9 \\
Nov 18 & 3 & 1 & 24 \\
& 3 & 2 & 2 \\
& 4 & 3 & 4 \\
& 4 & 4 & 0 \\
& 5 & 3 & 3 \\
& 5 & 4 & 10 \\
& 6 & 3 & 9 \\
& 6 & 4 & 14 \\
& 7 & 3 & 7 \\
Nov 25 & 7 & 4 & 12 \\
& 7 & 5 & 29 \\
& 8 & 5 & 41 \\
& 9 & 5 & 26 \\
\hline Totals & 9 & 5 & 280 \\
\hline
\end{tabular}

The combined analysis of 600 Rosewall 2011 BY (age three) and 2012 BY (age four) spawners born to the captive parents of 2008 provided a family structure indicating that the sampled fish were the product of 76 parents of one, and 86 parents of the other, gender. As expected, parents of both genders were polygamous; each parent had progeny assigned to between one and five mates. 
One hundred and fifty-nine matings were identified, each containing between 1 and 13 fullsib members. The age three fish spawned constituted members of 135 matings, whereas the age four fish were assigned to 65 matings. The 162 parental fish identified for progeny from the Rosewall $2008 \mathrm{BY}$ represented $21 \%$ of the 780 parents spawned in 2008, and the 159 matings accounted for $17 \%$ of the 934 recorded crosses (Table 4).

The hatchery-produced smolts that were sampled emigrating from Sakinaw Lake in 2013 were progeny of 2011 BY captive brood at Rosewall hatchery, whereas the natural smolts were progeny of reintroduced adults that returned to spawn in Sakinaw Lake in 2011. The reintroduced lake spawners of 2011 were believed to be primarily age four fish returning from the Rosewall 2007 brood derived almost entirely from the 2004 parental lineage (Table 4). Age three fish from the captive 2008 brood, with contributions from all three parental lineages, may also have returned to Sakinaw Lake in 2011, although not observed in video footage of adults passing through the fishway. The Rosewall $2011 \mathrm{BY}$ spawners consisted of both age three and four fish, with contributions from all three parental lineages (Table 4).

Maximum likelihood partitioning of hatchery smolts sampled in 2013 to families indicated that the progeny were produced by 61 female and 62 male parents, and confirmed that hatchery spawning was polygamous among parents of both sexes. Forty-three of 110 marked smolts were assigned to two sampled hatchery parents, 27 smolts were assigned to a single sampled parent and an unsampled or phantom parent, and the remaining 40 marked smolts were assigned to two phantom parents. Among the 43 smolts assigned to two sampled parents, 13 fullsib families with more than one smolt were identified; 12 of them contained two smolts and one fullsib family contained three smolts. Twenty-nine sampled mothers (each producing 1-3 progeny) and 30 sampled fathers (each producing 1-4 progeny) accounted for the 43 smolts. Approximately $85 \%$ of the assigned parents were age three. This is consistent with hatchery records that indicated $79 \%$ of Rosewall BY 2011 spawners were age three fish born in 2008 (Table 4).

\subsection{Effective Sizes of Wild, Captive and Reintroduced Sakinaw Sockeye Salmon}

The linkage-based estimates of effective brood sizes $\left(\mathrm{N}_{\mathrm{b}}\right)$ for the three parental founder groups of Sakinaw sockeye salmon were much less than that of the wild sample from 1988 (Table 6, Figure 4), as were those of the $F_{1}$ captive broods of 2005 and 2006 ( $F_{1}$ progeny of the P2002 founders). $\mathrm{N}_{\mathrm{b}}$ of the adult progeny was 12 for 2005 and 9 for 2006 (Table 6). These estimates are similar to the variance-based $\mathrm{N}_{\mathrm{b}}$ estimate of 9 for the BYs combined. Linkage-based $\mathrm{N}_{\mathrm{b}}$ estimates for the captive brood fish in later years increased as the numbers of fish spawned annually increased and all descendants of the three parental lineages were interbred (Table 6).

$\mathrm{N}_{\mathrm{b}}$ estimates for the 2013 hatchery and natural smolts were higher than those estimated for any of the Rosewall captive broods (Table 6, Figure 4). The hatchery smolt $\mathrm{N}_{\mathrm{b}}$ was more than double $\mathrm{N}_{\mathrm{b}}$ estimated for their 2011 BY parents, reflecting a successful reduction of linkage disequilibrium (family structure) in released hatchery smolts compared with their captive parents. $\mathrm{N}_{\mathrm{b}}$ of the natural smolts, progeny of fish that spawned in Sakinaw Lake in 2011, was less than of the hatchery smolts but also exceeded those for individual captive BYs at Rosewall hatchery, indicating that genetic 
diversity among the reintroduced adult spawners was high and many of them contributed successfully to smolt production during lake spawning.

Figure 4. Allelic richness (red bars) for a standardized sample size of 70 fish and effective brood size (blue bars) for adult and smolt groups of wild, captive and reintroduced Sakinaw lake sockeye salmon.

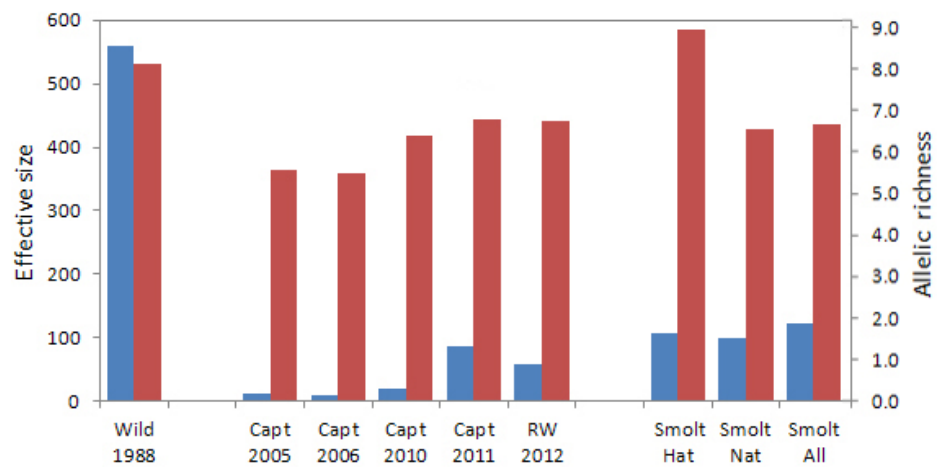

\subsection{Parental Lineage Contributions in Sakinaw Sockeye Salmon Hatchery Smolts}

Analysis of admixture confirmed that the genetic composition of the hatchery and natural smolts emigrating from Sakinaw Lake in 2013 were different (Table 8). In particular, the estimated contribution from the P2002 lineage was substantial in the natural smolts but nonexistent in the hatchery smolts. Hatchery smolts contained a strong influence of the P2004 lineage, which had been incorporated into both the age three and age four Rosewall 2011 BY spawners (Table 4). The analysis of approximately equal numbers of natural and hatchery smolts combined indicated that all three founder groups made substantial genetic contributions to the 2013 smolt emigration (Table 8). In fact, hatchery smolts were eight times more numerous than natural smolts and there was likely limited contribution from P2002 in the overall smolt emigration.

Table 8. Maximum likelihood (ML) and moment (M) estimates of contributions of three parental founding groups (P2002, P2004, P2005) of Sakinaw Lake sockeye salmon to smolts produced in 2013 by adults that spawned in captivity (hatchery smolts) or in Sakinaw Lake (natural smolts). The 95\% confidence intervals (CI) for the moment values shown in brackets were derived from bootstrapping over the 14 microsatellite loci.

\begin{tabular}{ccccccc}
\hline \multirow{2}{*}{ Smolt Sample } & \multicolumn{2}{c}{ P2002 } & \multicolumn{2}{c}{ P2004 } & \multicolumn{2}{c}{ P2005 } \\
\cline { 2 - 7 } & ML & M & ML & M & ML & M \\
\hline \multirow{2}{*}{ Hatchery } & 0.00 & -0.04 & 0.58 & 0.51 & 0.42 & 0.53 \\
& \multicolumn{2}{c}{$(-0.15-0.7)$} & \multicolumn{2}{c}{$(0.40-0.65)$} & \multicolumn{2}{c}{$(0.44-0.59)$} \\
Natural & 0.45 & 0.46 & 0.40 & 0.40 & 0.15 & 0.14 \\
& $(0.34-0.56)$ & \multicolumn{2}{c}{$(0.30-0.51)$} & $(0.07-0.24)$ \\
All & 0.24 & 0.26 & 0.50 & 0.44 & 0.26 & 0.30 \\
& $(0.15-0.37)$ & & $(0.34-0.56)$ & \multicolumn{2}{c}{$(0.24-0.37)$} \\
\hline
\end{tabular}




\section{Discussion}

The Sakinaw Lake sockeye salmon population has been reintroduced to its natural environment after a four year period of extirpation and will potentially become re-established and self-sustaining. Genetic diversity from the founding parental fish, although limited, has been retained in the captive breeding program, but domestication may have occurred in the closed population. The absence of migratory adult fish, wild or hatchery-produced, in the natural environment between 2006 and 2009 necessitated the "recycling" of captive fish through the breeding program as soon as maturation in captivity occurred. Thus, the majority of the $\mathrm{F}_{2}$ generation experienced only the hatchery environment, although small numbers of them were the basis of the first adult returns to Sakinaw Lake in 2010 and 2011. Fish with a longer captive ancestry generated the Sakinaw Lake adult returns in 2012 and 2013, and will also constitute future returns of hatchery fish. Re-adaptation to the wild environment will require the successful return and subsequent spawning of natural smolts from Sakinaw Lake.

Freshwater survivals from egg to smolts were variable over the program history, but may have been similar to that of wild fry prior to population collapse. The natural smolts of captively-bred fish that spawned in Sakinaw Lake in 2011 experienced a freshwater survival of 4.3\%, comparable to that observed historically for wild spawners in Sakinaw Lake. Sakinaw sockeye salmon survivals in freshwater compare favourably to egg to smolt survival and egg to fry survival estimates from other sockeye salmon populations ( $2 \%$ across 7 populations and $7 \%$ across 9 populations, respectively; reviewed in [48]). This suggests that the freshwater phase of Sakinaw sockeye salmon life history is not currently limiting their productivity.

Marine survivals have recently improved from essentially zero for the 2006-2009 period, but remain extremely low. A marine survival rate of $1.8 \%$ would be required for the natural smolts of 2013 to replace their parental population of 517 fish. While this rate is typical of historical values estimated for Sakinaw sockeye salmon, it is over twice that observed for recent return years. Approximately $30 \%$ of males among the captively-bred adults that returned to Sakinaw Lake in 2013 were visually identified as small age three fish, and their return may portend a high return of age four fish in 2014. At any rate, marine survival rates must improve before current numbers of captive fish returning to spawn in Sakinaw Lake will be sufficient to rebuild the population in the absence of ongoing hatchery supplementation.

The original abundance-based goals for the recovery actions, including captive breeding, were rendered unrealistic once loss of the wild population occurred in 2006. The captive breeding program was implemented, but constituted a population bottleneck with its 84 adult founders. The genetic analyses conducted in this study indicated that allelic richness and effective size of annual captive brood samples were initially low due to founder effects, but increased over time as captive fish from the three founding groups were interbred in captivity. As a result, the genetic distances between preextirpation wild Sakinaw fish and reintroduced naturally-spawned Sakinaw sockeye salmon were no greater than between the wild population sample and wild parental founders of the captive breeding program. The effective sizes of reintroduced Sakinaw sockeye salmon hatchery and natural smolts samples, individually and combined, were greater than the number of founding parents used for the 
captive program. This indicated that parental contributions were maintained and genetic drift was not exacerbated in captivity.

Pedigree management in captivity was successful in melding the founding parental lineages into annual spawning assemblages that became individually more diverse (higher allelic richness and effective size) and similar to a wild population sample, but collectively more homogenous (lower $\mathrm{F}_{\mathrm{ST}}$ values among captive BYs) over time. Nevertheless, genetic differentiation was observed between the small samples of reintroduced adults that returned to Sakinaw Lake in 2011 and 2012, corresponding to genetic characteristics of the captive broods from which they were derived. Differentiation between the natural and captive smolts sampled in 2013 also indicated that variation among hatchery broods had not been eliminated and that captive fish may continue to increase the effective, as well as the census, number of breeders in Sakinaw Lake for several years.

The family assignments of 600 fish arising from the Rosewall captive brood of 2008 and retained for future breeding indicated they may have been derived from as few as 159 matings created with 162 parental fish. Only 37\% of the age three progeny were sampled in 2011 and the unsampled fish undoubtedly included many from parents and matings not represented in the sampled fish. However, even the optimistic assumption that an additional 162 parents were involved in production of the unsampled progeny would only bring the total parental representation to 324 , or $42 \%$ of the 780 recorded brood fish of 2008. Thus, it seems likely that the selection process and survival pattern of fish retained for captive breeding each year at Rosewall hatchery has been repeatedly resulting in the exclusion of some fullsib families and some entire parental contributions. This would limit the beneficial increases in $\mathrm{N}_{b}$ and $\mathrm{A}_{\mathrm{R}}$ within the captive program achieved by spawning fish between age and pooled family groups. While the total genetic diversity resulting from captive spawning each year should be represented in the hatchery fry released to Sakinaw Lake, much less is apparently retained until maturity in the captive fish.

Analysis of the hatchery smolts emigrating from Sakinaw Lake in 2013 supports the idea that a substantial proportion of successful parents are not contributing to juvenile fish retained for captive breeding. The $\mathrm{N}_{\mathrm{b}}$ estimate for hatchery smolts of 2013 was 207 , over twice that estimated for any captive brood, including the parental captive brood of 2011. The reduced pairwise linkage disequilibrium and higher effective size of the smolts compared to their captive parents indicates that the captive crossing design was successful in reducing average relatedness, and therefore linkage disequilibrium between loci, in the progeny relative to the parents. Approximately $40 \%$ of the parent pairs of fish constituting the 2011 captive brood were sampled and $39 \%$ of the hatchery smolts were assigned to the sampled parental fish in family analysis. This indicates that, in 2013, emigrating hatchery smolts were representative of the entire parental brood, unlike the juveniles retained in captivity from the 2008 captive brood.

The collection process for captive juveniles has been to withdraw 1,500 fry from two or three pooled groups of juvenile fish. Given the large number of parental fish and individual matings created each year, and variation in progeny production among parents, it is likely that many matings are not represented among selected juveniles. Thus, the selection of one or two individuals, as fertilized eggs or newly-hatched juveniles, from each mating prior to progeny pooling could be considered as a means to improve retention of parental contributions in the captive brood. Mortality of captive fish prior to maturity would still result in the loss of some matings and parental contributions in each progeny 
cohort. However, survival to maturity at Rosewall has been $\geq 50 \%$ each year, and has increased over time with improved husbandry. Improving family representation in the captive fish retained for breeding may facilitate increases of $\mathrm{N}_{\mathrm{b}}$ in future captive broods.

It is interesting to note that $\mathrm{N}_{\mathrm{b}}$ estimated for the natural smolts of 2013 was also higher than that of any sampled Rosewall hatchery captive brood. Reintroduced adults that returned to spawn in Sakinaw Lake in 2011 were derived from the 2007 BY hatchery juvenile releases which, like the hatchery smolts of 2013, may have had a higher $\mathrm{N}_{\mathrm{b}}$ than their counterparts retained in captivity; if so, the higher effective size was retained through adult return to, and natural spawning in, Sakinaw Lake. Alternately, the assumption that the natural smolts resulted only from parental fish returning from 2007 BY hatchery fry releases may be incorrect.

Three alleles (one each in three different smolts at three different microsatellite loci) were observed in the natural smolts that were not observed in samples of captive brood or hatchery smolts. One of these alleles was observed the wild, adult Sakinaw sockeye salmon sampled in 1988, the other two were not. These alleles may have arisen through mutation or genotyping error, but no novel alleles were observed in the hatchery smolts. Age three and/or five hatchery-produced fish may also have returned to Sakinaw Lake in 2011, but would not be expected to carry alleles not previously sampled in the captive brood. Adult sockeye salmon from a different population may have strayed into Sakinaw Lake in 2011, but no distinctive genotypes were observed among the small numbers of adults sampled from the lake and beach-spawning sockeye salmon populations are uncommon in the vicinity.

A final possibility is that non-anadromous O. nerka, either resident kokanee or residualized (nonmigratory) sockeye salmon, were present in Sakinaw Lake and participated in spawning in 2011. Mature residualized sockeye salmon in 2011 would have been born during the period of extirpation for anadromous fish (2006-2009, inclusive), reducing the likelihood of their presence. Genetically distinct kokanee do exist in Sakinaw Lake but have not been characterized at microsatellite loci. Sakinaw Lake kokanee are believed capable of survival and return to the lake if forced to enter the marine environment [49]. Analysis of the natural smolts with various methods to detect the presence of purebred or hybrid individuals from another population provided no significant indication of two populations or admixed hybrids (data not shown). Analysis of Sakinaw Lake kokanee and larger smolt samples in future years may provide sufficient information to clarify the origin(s) of natural smolts.

Genetic differentiation of hatchery and natural smolts was reflected in the admixture analysis, which indicated the two groups were differentially influenced by the three groups of parental founders. The natural smolts, progeny of fish released from the 2007 BY captive brood, were expected to be primarily derived from the P2004 founders, although four age five fish were included in the 2007 captive brood. These were age five $F_{1}$ progeny of P2002 parents. They may have had a disproportionate influence, reflecting random or selective processes, on the reintroduced adults that returned to Sakinaw Lake in 2011. Alternately, the genetic contributions attributed to P2002 and P2005 parents in the admixture analysis of the natural smolts may in fact reflect participation of other fish (age three or five reintroduced fish or resident adults, as discussed above) in spawning in Sakinaw Lake in 2011.

Approximate equalization of parental contributions to the fish reared in the captivity is practical and potentially beneficial, but not so for the fish released to the natural environment each year. Given the low abundance of Sakinaw Lake sockeye salmon over the past decade, and the resultant COSEWIC 
endangered classification of the population, there is no justification for the destruction of individuals that might contribute to population restoration in the natural environment. In 2013, the hatchery and natural smolts constituted different genetic entities, and the parental founding contributions to the combined smolt emigration would have been more equal if hatchery smolts had not so greatly outnumbered natural smolts. However, the Sakinaw population likely remains imperilled more by low abundance and poor marine survival than by low genetic diversity. If naturally-spawned smolts survive the ocean migration and begin contributing to adult population recovery, an overall reduction and increased standardization of hatchery family contributions in released juveniles may become feasible.

Actions implemented to rebuild the natural Sakinaw Lake sockeye salmon population have not yet achieved a consistent adult return of 500 captively-bred individuals, much less the original conservation goal of 500 natural spawners. Terminal fishery exploitation rates for Sakinaw sockeye salmon are difficult to estimate while the population is at low abundance but ranged from $7 \%$ to $21 \%$ for 2010 and 2011 (data not shown). These rates are towards the lower end of those estimated for Sakinaw sockeye salmon during the 1970s through 1990s, which ranged from $1 \%$ to $67 \%$ [27]. The control of terminal harvest mortality in recent years has been facilitated by concurrent low abundances and conservation efforts implemented for co-migrating Fraser River sockeye salmon populations [50]. Improved husbandry for captive brood and maintenance of harvest control, facilitated by rapid non-lethal genetic detection of Sakinaw sockeye salmon in pre-fishery sampling, has likely contributed to the recent successful return of fish from captive releases and may also benefit rebuilding of the small natural population. Modelling efforts [13,22] indicate that supplementation for several more years may not prevent re-adaptation to the natural environment. Nevertheless, the timeframe for anticipated successful recovery of a natural population with ongoing supplementation is limited to several more generations.

Extirpation of the wild Sakinaw population has precluded possible replacement of the existing captive brood with natural counterparts other than early descendants of the captive program itself. Consideration may be given to captive brood "refreshment" or replacement with adult reintroduced fish that survive to return to Sakinaw Lake or their naturally spawned progeny captured during smolt emigration. However, the genetic limitations to domestication avoidance by the alternation of generations through the captive and natural environments have been noted [22]. Milt cryopreservation from both captive males and reintroduced males that return to Sakinaw Lake is currently under investigation as an additional measure to conserve existing diversity and reduce risk of operational (hatchery) failure in the captive breeding program.

\section{Conclusions}

The initial success of the Sakinaw Lake sockeye salmon captive breeding program has provided a basis for reintroduction of the natural population after temporary extirpation. However, marine survivals remain low and limiting to natural population recovery. Continued hatchery supplementation, possibly at lower levels, will likely be required for restoration of a self-sustaining natural population in the short timeframe dictated by practical and theoretical considerations. Implementation of simple steps to increase family representation among fish maintained in captivity to increase retention of diversity in the captive brood program is feasible. The likelihood of long-term success in population 
recovery may be improved by a shift in emphasis of recovery efforts from captive breeding to further reductions in mixed-stock fishery mortality, the only aspect of marine survival for which management options exist.

\section{Acknowledgments}

We are indebted to all members of the Sakinaw recovery team who developed the rationale and goals for much of the work conducted in this study. Steve Baillie, Ian Matthews and Grant McBain organized the field programs associated with this project. The Sechelt First Nation, James Cameron, Pender Harbour and District Wildlife Society and Iris Griffith Conservation Center all provided assistance with field sampling and habitat restoration on Sakinaw Lake. Les Clint, Ian Seaton and other DFO salmon enhancement personnel maintained high standards of fish husbandry, sampling and record keeping in the captive breeding program. Jim Wilson performed fish culture at Ouillet hatchery and assisted with enumeration of both spawning adults and smolts and conducted habitat restoration in Sakinaw Lake under contract. We thank the Pacific Salmon Commission for use of their test fishery data in which Sakinaw sockeye salmon were identified by genetic means. Michael Folkes kindly provided his estimates of marine survival for captively-bred Sakinaw sockeye salmon returning to Sakinaw Lake in 2010 and 2011. Three reviewers made many helpful suggestions that improved our study.

\section{Author Contributions}

Ruth Withler initiated the study, supervised genetic analyses and prepared the manuscript outline. Janine Supernault compiled the genetic data, performed genetic analyses and contributed to manuscript revision. David O'Brien and Nicolette Watson compiled and analyzed the assessment data and participated in manuscript preparation and revision.

\section{Conflicts of Interest}

The authors declare no conflict of interest.

\section{References and Notes}

1. Taylor, E.B. A review of local adaptation in Salmonidae, with particular reference to Pacific and Atlantic salmon. Aquaculture 1991, 98, 185-207.

2. Hilborn, R.; Quinn, T.P.; Schindler, D.E.; Rogers, D.E. Biocomplexity and fisheries sustainability. PNAS 2003, 100, 6564-6568.

3. Reisenbichler, R.; Utter, F.M.; Krueger, C.C. Genetic concepts and uncertainties in restoring fish populations and species. In Strategies for Restoring River Ecosystems: Sources of Variability and Uncertainty in Natural and Managed Systems; Wissmar, R.C., Bisson, P.A., Duke, M., Eds.; American Fisheries Society: Bethesda, MD, USA, 2003; pp. 149-183.

4. Waples, R.S. Pacific salmon, Oncorhynchus spp., and the definition of "species" under the Endangered Species Act. Mar. Fish. Rev. 1991, 53, 11-22.

5. Waples, R.S. Evolutionarily significant units and the conservation of biological diversity under the Endangered Species Act. In Evolution and the Aquatic Ecosystem: Defining Unique Units in 
Population Conservation; Nielsen, J.L., Ed.; American Fisheries Society: Bethesda, MD, USA, 1995; pp. 8-27.

6. Irvine, J.R.; Gross, M.R.; Wood, C.C.; Holtby, L.B.; Schubert, N.D.; Amiro, P.G. Canada's Species at Risk Act: An opportunity to protect “endangered” salmon. Fisheries 2005, 30, 11-19.

7. DFO (Fisheries and Oceans Canada). Canada's Policy for Conservation of Wild Pacific Salmon. Available online: http://www.pac.dfo-mpo.gc.ca/publications/pdfs/wsp-eng.pdf (accessed on 20 December 2013).

8. Groombridge, J.J.; Raisin, C.; Bristol, R.; Richardson, D.S. Genetic consequences of reintroductions and insights from population history. In Reintroduction Biology: Integrating Science and Management; Ewen, J.G., Armstrong, D.P., Parker, K.A., Seddon, P.J., Eds.; Wiley-Blackwell: Chichester, UK, 2012; pp. 395-440.

9. Ewing, S.R.; Nager, R.G.; Nicoll, M.A.C.; Aumjaud, A.; Jones, C.G.; Keller, L.F. Inbreeding and loss of genetic variation in a reintroduced population of Mauritius kestrel. Conserv. Biol. 2008, 22, 395-404.

10. Armstrong, D.P.; Seddon, P.J. Directions in reintroduction biology. Trends Ecol. Evolut. 2008, $23,20-25$.

11. Kalinowski, S.T.; van Doornik, D.M.; Kozfkay, C.C.; Waples, R.S. Genetic diversity in the Snake River sockeye salmon captive broodstock program as estimated from broodstock records. Conserv. Genet. 2012, 13, 1183-1193.

12. O'Reilly, P.T.; Harvie, C.J. Conservation of genetic variation in the inner Bay of Fundy Atlantic salmon captive breeding and rearing program. Canadian Science Advisory Secretariat Research Document 2009/095. Available online: http://www.dfo-mpo.gc.ca/CSAS/Csas/publications/ resdocs-docrech/2009/2009_095_e.pdf (accessed on 20 December 2013).

13. Bowlby, H.D.; Gibson, A.J.F. Reduction in fitness limits the useful duration of supplementary rearing in an endangered salmon population. Ecol. Appl. 2011, 21, 3032-3048.

14. Bradford, M.J.; Hume, J.M.B.; Withler, R.E.; Lofthouse, D.; Barnetson, S.; Grant, S.; Folkes, M.; Schubert, N.; Huang, A.-M. Status of Cultus Lake sockeye salmon. DFO Canadian Science Advisory Secretariat Research Document 2010/123. Available online: http://www.dfo-mpo.gc.ca/ CSAS/Csas/publications/resdocs-docrech/2010/2010_123_e.pdf (accessed on 20 December 2013).

15. Withler, R.E.; Devlin, R.H.; Latham, S.; Wood, C.C.; Supernault, K.J. Analysis of gene origin in the first adult returns to the Cultus sockeye salmon captive breeding program. Conserv. Genet. 2011, 12, 1469-1483.

16. Frankham, R. Conservation genetics. Annu. Rev. Genetics 1995, 29, 305-327.

17. Fraser, D.J. How well can captive breeding programs conserve biodiversity? A review of salmonids. Evolut. Appl. 2008, 1, 535-586.

18. McClure, M.M.; Utter, F.M.; Baldwin, C.; Carmichael, R.W.; Hassemer, P.F.; Howell, P.J.; Spruell, R.; Conney, T.D.; Schaller, H.A.; Petrosky, C.E. Evolutionary effects of alternative artificial propagation programs: Implications for viability of endangered anadromous salmonids. Evolut. Appl. 2008, 1, 356-375.

19. Waples, R.S.; Do, C. Genetic risk associated with supplementation of Pacific salmonids: Captive broodstock programs. Can. J. Fish. Aquat. Sci. 1994, 51, 310-329. 
20. Allendorf, F.W. Delay of adaptation to captive breeding by equalizing family size. Conserv. Biol. 1993, 7, 416-419.

21. Williams, S.E.; Hoffman, E.A. Minimizing genetic adaptation in captive breeding programs: A review. Biol. Conserv. 2009, 142, 2388-2400.

22. Lynch, M.; O'Hely, M. Captive breeding and the genetic fitness of natural populations. Conserv. Genet. 2001, 2, 363-378.

23. Ford, M.J. Selection in captivity during supportive breeding may reduce fitness in the wild. Conserv. Biol. 2002, 16, 815-825.

24. Ford, M.J.; Murdoch, A.; Howard, S. Early male maturity explains a negative correlation in reproductive success between hatchery-spawned salmon and their naturally spawning progeny. Conserv. Lett. 2012, 5, 450-458.

25. Araki, H.; Cooper, B.; Blouin, M.S. Carry-over effect of captive breeding reduces reproductive fitness of wild-born descendants in the wild. Biol. Lett. 2009, 5, 621-624.

26. Gustafson, R.G.; Waples, R.S.; Myers, J.M.; Weitkamp, L.A.; Bryant, G.J.; Johnson, O.W.; Hard, J.J. Pacific salmon extinctions: Quantifying lost and remaining diversity. Conserv. Biol. 2007, 21, 1009-1020.

27. Murray, C.; Wood, C.C. Status of Sakinaw Lake sockeye salmon (Oncorhynchus nerka). Canadian Science Advisory Secretariat Research Document 2002/088. Available online: http://www.dfo-mpo.gc.ca/csas-sccs/publications/resdocs-docrech/2002/2002_088-eng.htm (accessed on 20 December 2013).

28. COSEWIC. Assessment and Status Report on the Sockeye Salmon Oncorhynchus nerka Sakinaw Population in Canada. Available online: http://www.sararegistry.gc.ca/virtual_sara/files/cosewic/ sr_sockeye_salmon_e.pdf (accessed on 20 December 2013).

29. Gustafson, R.G.; Wainwright, T.C.; Winans, G.A.; Waknitz, F.W.; Parker, L.T.; Waples, R.S. Status Review of Sockeye Salmon from Washington and Oregon; NOAA Technical Memorandum NMFS-NWFSC-33; U.S. Dep. Commer.: Washington, DC, USA, December 1997.

30. Nelson, R.J.; Wood, C.C.; Cooper, G.; Smith, C.; Koop, B. Population structure of sockeye salmon of the central coast of British Columbia: implications for recovery planning. North Amer. J. Fish. Manag. 2003, 23, 703-720.

31. Beacham, T.D.; Beamish, R.J.; Candy, J.R.; Tucker, S.; Moss, J.H.; Trudel, M. Stock-specific migration pathways of juvenile sockeye salmon in British Columbia waters and in the Gulf of Alaska. Trans. Amer. Fish. Soc. 2014, in press.

32. R Core Team. R: A Language and Environment for Statistical Computing. Available online: http://www.R-project.org/ (accessed on 20 December 2013).

33. Beacham, T.D.; Candy, J.R.; McIntosh, B.; MacConnachie, C.; Tabata, A.; Kaukinen, K.; Deng, L.; Miller, K.M.; Withler, R.E.; Varnavskaya, N.V. Estimation of stock composition and individual identification of sockeye salmon on a Pacific Rim basis using microsatellite and major histocompatibility complex variation. Trans. Amer. Fish. Soc. 2005, 134, 1124-1146.

34. Banks, M.A.; Blouin, M.S.; Baldwin, B.A.; Rashbrook, V.K.; Fitzgerald, H.A.; Blankenship, S.M.; Hedgecock, D. Isolation and inheritance of novel microsatellites in Chinook salmon (Oncorhynchus tshawytscha). J. Hered. 1999, 90, 281-288. 
35. Beacham, T.D.; Margolis, L.; Nelson, R.J. A comparison of methods of stock identification for sockeye salmon (Oncorhynchus. nerka) in Barkley Sound, British Columbia. North Pacific Anadromous Fish. Comm. Bull. 1998, 1, 227-239.

36. Nelson, R.J.; Beacham, T.D. Isolation and cross species amplification of microsatellite loci useful for study of Pacific salmon. Anim. Genet. 1999, 30, 228-229.

37. Smith, C.T.; Koop, B.F.; Nelson, R.J. Isolation and characterization of coho salmon (Oncorhynchus kisutch) microsatellites and their use in other salmonids. Mol. Ecol. 1998, 7, 1613-1621.

38. Scribner, K.T.; Gust, J.R.; Fields, R.L. Isolation and characterization of novel salmon microsatellite loci: Cross-species amplification and population genetic applications. Can. J. Fish. Aquat. Sci. 1996, 53, 833-841.

39. Morris, D.B.; Richard, K.R.; Wright, J.M. Microsatellites from rainbow trout (Oncorhynchus mykiss) and their use for genetic study of salmonids. Can. J. Fish. Aquat. Sci. 1996, 53, 120-126.

40. Goudet, J. FSTAT, A Program to Estimate and Test Gene Diversities and Fixation Indices, version 2.9.3. Available online: http://www2.unil.ch/popgen/softwares/fstat.htm (accessed on 20 December 2013)

41. Huson, D.H.; Bryant, D. Application of phylogenetic networks in evolutionary studies. Mol. Biol. Evolut. 2006, 23, 254-267.

42. Wang, J. Sibship reconstruction from genetic data with typing errors. Genetics 2004, 166, 1963-1979.

43. Wang, J. An improvement on the maximum likelihood reconstruction of pedigrees from marker data. Heredity 2013, 111, 165-174.

44. Waples, R.S.; Do, C. LDNE: A program for estimating effective population size from data on linkage disequilibrium. Mol. Ecol. Resour. 2008, 8, 753-756.

45. Waples, R.S. Salmonid insights into effective population size. In Evolution Illuminated: Salmon and Their Relatives; Hendry, A.P., Stearns, S.C., Eds.; Oxford University Press: Oxford, UK, 2004; pp. 295-314.

46. Wang, J. Maximum-likelihood estimation of admixture proportions from genetic data. Genetics 2003, 164, 747-765.

47. Roberts, D.F.; Hiorns, R.W. Methods of analysis of the genetic composition of a hybrid population. Human Biol. 1965, 37, 38-43.

48. Bradford, M.J. Comparative review of Pacific Salmon survival rates. Can. J. Fish. Aquat. Sci. 1995, 52, 1327-1338.

49. Wood, C.C.; Welch, D.W.; Godbout, L.; Cameron, J. Marine migratory behavior of hatchery-reared anadromous and wild non-anadromous sockeye salmon revealed by acoustic tags. Amer. Fish. Soc. Symp. 2012, 76, 289-311.

50. Macdonald, J.S.; Patterson, D.A.; Hague, M.J.; Guthrie, I.C. Modeling the influence of environmental factors on spawning migration mortality for sockeye salmon fisheries management in the Fraser River, British Columbia. Trans. Amer. Fish. Soc. 2010, 139, 768-782.

(C) 2014 by the authors; licensee MDPI, Basel, Switzerland. This article is an open access article distributed under the terms and conditions of the Creative Commons Attribution license (http://creativecommons.org/licenses/by/3.0/). 